\title{
GLASSWORT - A SALT-LOVING PLANT
}

\author{
by R. E. REDMANN*
}

While driving through the prairies rost people at one time or another ave noticed a reddish tint to the horelines of many of our saline loughs. Those curious enough to xamine more closely probably have pund a strange little succulent and vafless plant, glasswort (Salicornia ubra). The species name, rubra, is atin for red, and during the latter ortion of the growing season the name very appropriate. The common ame, glasswort, is also apt, since the ucculent stems have a glassy apearance and tend to crunch under the eet as if one were walking on delicate rystal.

Our species is a relative of a number $f$ species of Salicornia found along the eacoasts of North America. An specially close relative is samphire Salicornia europaea) which can be pund in the salt marshes of both the ast and west coasts of North America.

The culinary value of the samphire as recognized by the early settlers ho recalled using the European samhire as a salad, pickle or pot-herb. uell Gibbons discusses the use of amphire for food and includes his ersonal recipe for samphire pickles! I ave substituted glasswort in the ecipes and found the results quite alatable.

Glasswort adds a salty tang to a

Department of Plant Ecology,

University of Saskatchewan, Saskatoon tossed salad, and the glasswort pickles are a unique treat. I have not bothered cooking it up as a pot herb - it is a member of the spinach family (Chenopodiaceae) and I have never overcome my childhood dislike of that vegetable. Whether the flavour is similar or not I cannot say.

The salty taste of glasswort is a simple clue to the intriguing physiology and ecology of this species. It is one of the most salt tolerant plants to be found in the whole world. In the saline sloughs and lakes of the prairies it is found closest to the center of dry saline depressions where no other vascular plant can grow. Salt concentrations as high as 5 percent have been measured in soils where glasswort grows; one can frequently observe salt crystals around the base of the plant and a white salt crust on the soil surface between the scattered plants. (The most important salt is sodium chloride, common table salt.) As the salinity decreases away from the center of the saline area, distinct bands of vegetation dominated by other salttolerant species can be observed: sea blite, Suaeda depressa: salt-grasses, Puccinellia nutalliana and Distichlis stricta, and a few others.

The question of just how plants such as Salicornia rubra are able to tolerate extremely high levels of salts has been studied by botanists for many years. The approach of the plant is basically to fight fire with fire, or more precisely, to fight salt with salt. The 


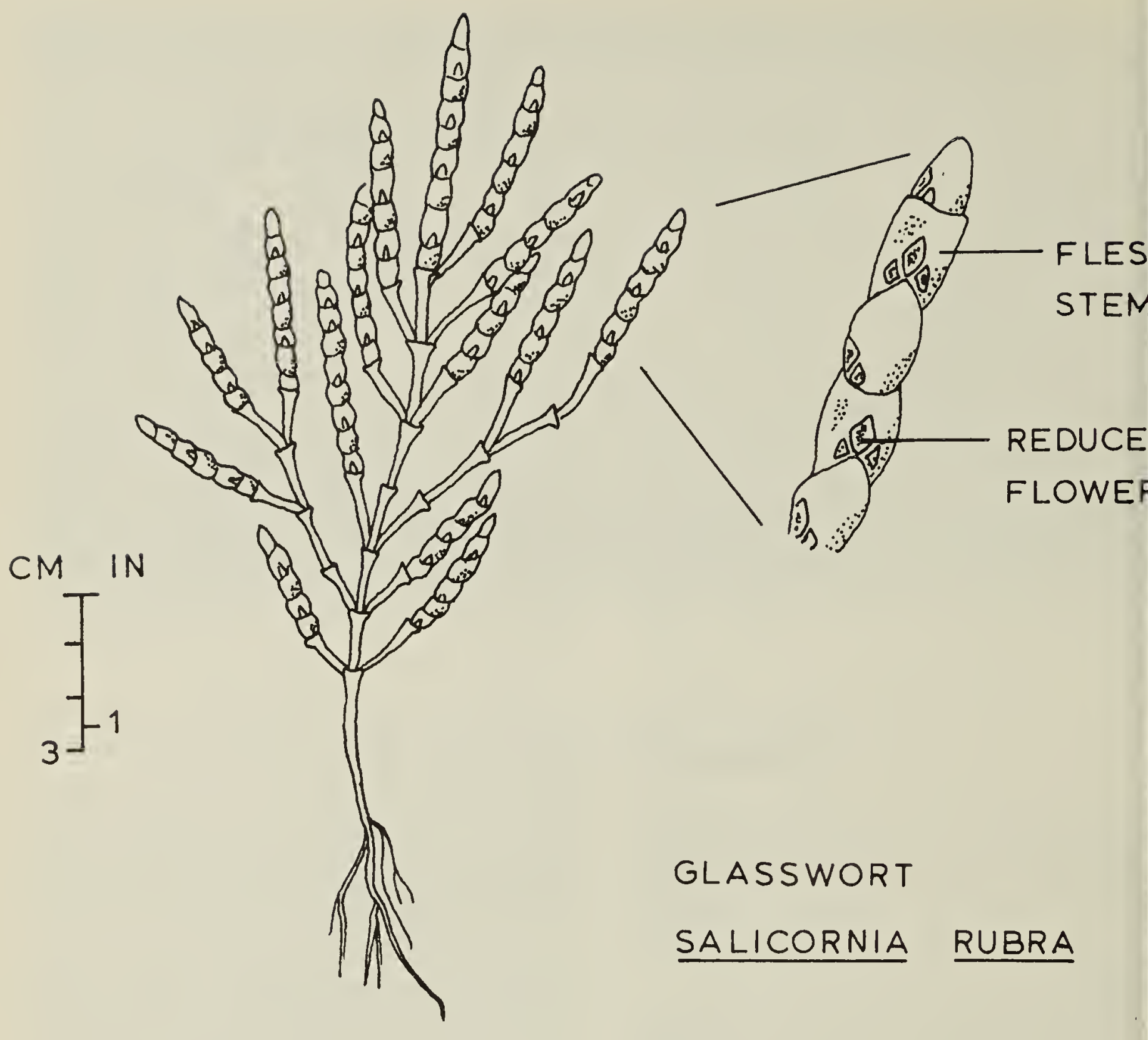

salty tang of the plant indicates that glasswort accumulates salt in its tissue. It does this in order to maintain a proper gradient for water uptake. Salts dissolved in water decrease the ability of water to diffuse. An ordinary plant growing in saline soils could actually lose water to the soil because the activity of the water in the plant (i.e., its ability to diffuse) is greater than that in the soil. The plant wilts and then dies of drought. Glasswort gets around this problem by accumulating salts until the balance is such that water must diffuse into the plant. Salt contents as high as 30 percent have been found the tissue of plants like glasswort. Th is not the complete solution to th problem, however. Too much sa disrupts the functioning of ordinat plant cells by disturbing enzymes (th compounds basic to the chemistry life). Glasswort has evolved enzym systems that are tolerant of salts, an also has the means of localizing sal by accumulating them in out-of-th way corners of the cells and tissue The stored salt may eventually $t$ eliminated by simply shedding sho segments where it has accumulated. 
These are the basic problems of salt lerance in plants. Of course the acual mechanisms are much more comlex than I have indicated - plant cologists and physiologists are still rying to understand them fully. Think bout the problems of salt tolerance gain when you eat your glasswort alad or munch your samphire pickles.

\section{Recipe for Samphire (Glasswort) Pickles 1}

Wash freshly picked glasswort. Pack pint jars with stems straight and vercal.
Make a pickle of: 1 qt. vinegar, 1/2 cup sugar, 3 tablespoons mixed pickling spices, 1 slice onion and 6 bayberry leaves.

Boil together for $10 \mathrm{~min}$. Pour boiling hot over glasswort until jars are full. Seal and store 3 weeks before broaching.

'Euell Gibbons, Stalking the Blue-Eyed Scallop, David McKay Co., Publ., N.Y. 1964.

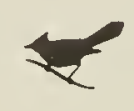

\title{
TADPOLE SHRIMPS IN
}

\section{BEAVER CREEK, SASKATCHEWAN}

\author{
by JOHN R. LAWRENCE*
}

Tadpole shrimps (Class Crustacea, Division Eubranchipoda, Order lotostraca) are characteristic habitants of temporary ponds and ools. They are not considered to ocur in large water bodies and flowing ystems. Two specimens of Lepidurus ouesi (Packard), were found in a lowing stream, Beaver Creek, Saskathewan, about 10 miles south of askatoon, on June 28, 1974. (Figs. 1 nd 2) This observation is noted and he life history of the Eubranchipods tadpole shrimps, fairy or brine hrimps and clam shrimps are iscussed, based on Pennak except here noted otherwise. ${ }^{6}$

Department of Biology,

University of Saskatchewan,

Saskatoon, Saskatchewan.
Tadpole shrimps get their name from their resemblance to tadpoles when swimming. According to Pennak, they may be gray, blue, green, and orange or reddish. Green and reddish tones predominated in the collected specimens. Colour is largely dependent on the food ingested.

Notostraca have sessile, compound eyes, a large shield-like carapace covering most of the body, and 35 to 71 pairs of legs (Fig. 3). Neither the number of legs nor the number of segments is constant within a species. ${ }^{4}$ The head forms a well defined body region; the trunk however, is not clearly divisible into thorax and abdomen. So difficult is it to define segments in these shrimps that they are referred to as to body rings. ${ }^{4}$ 